\title{
Assessing Safe Spaces for Digital Scholarship in the Library
}

\author{
Rachel Wexelbaum \\ James W. Miller Learning Resources Center, \\ St. Cloud State University, USA \\ rswexelbaum@stcloudstate.edu
}

\begin{abstract}
Background. Academic libraries, and the students and faculty that they serve, have different definitions of safe space. The attempts of both parties to construct a safe space for digital scholarship in the library can clash based on these divergent perspectives. While the number of academic libraries providing some form of digital scholarship support is increasing, the library definition of safe space, as well as the working culture of the library, has the potential to render libraries unsafe spaces for innovation and digital scholarship.

Objectives. The author of this paper will address the challenges that academic libraries face in creating safe spaces for digital scholarship. Major challenges include differences in working and leadership styles among different librarians, as well as the library's assumption that academic libraries automatically function as safe spaces. Results. To date no safe space assessment tool exists specifically for academic libraries or any organization that wishes to provide STEM (Science, Technology, Engineering and Math) related education. Using models for organizational change and strategic planning, the author proposes a series of recommendations and questions that academic libraries seeking to implement or improve digital scholarship services should investigate.
\end{abstract}

\section{INTRODUCTION}

Digital scholarship is an emerging trend in multiple academic disciplines. Faculties in the humanities, social sciences, and Science, Technology, Engineering and Math (STEM) fields are teaching students new forms of research, rhetoric, expression, and visualization of data using emerging media. Their students learn text encoding, data carpentry ${ }^{1}$, how to build online collections and exhibits, and how to make their work accessible to the public-while complying with copyright, fair use, public performance rights, and digital rights management. Academic libraries attempt to keep up with these trends by providing digital scholarship centers, digital media studios, creativity labs, makerspaces, co-working spaces, and other physical spaces that support this type of interdisciplinary experiential learning. Students curious about coding, digital storytelling, and other forms of digital scholarship can thus seek a safe place to learn these skills among peers and friendly, helpful mentors.

${ }^{1}$ Skills needed for retrieving, viewing, managing, and manipulating data for analysis in a way that is open and reproducible. These skills may soon become the norm in all research disciplines. 
The purpose of digital scholarship is not simply to learn about technology, but also to use new media and technology to improve the human condition. When planning spaces for digital scholarship, academic libraries focus on furniture, hardware, and software. People, including employees who will work in the space and patrons who will occupy and use the space, are often a secondary focus. While library employees who work in spaces for digital scholarship may have the technical and pedagogical expertise necessary for such work, they may not have the training required to create a safe space for digital scholarship. In fact, the organizational culture of the library itself may not reflect the open, exploratory, collaborative philosophy that shapes the culture of digital scholarship.

Most publications praise digital scholarship in libraries as a smart practice, but do not address potential cultural barriers that could hinder library-generated digital scholarship initiatives. This blind spot creates the illusion that all academic libraries have a culture that would create safe, open spaces for digital scholarship. For this reason, libraries engaged in digital scholarship initiatives should reassess and change their culture in order to re-envision the library as a safe space for digital scholarship. This would include developing a safe space within the organization for library employees to explore emerging technologies and media to learn new skills, as well as building safe spaces for collaborative learning among mixed groups of library employees, faculty, and students.

\section{DEFINING DIGITAL SCHOLARSHIP AND SAFE SPACE}

Before defining digital scholarship and how it manifests in libraries, it is important to provide a definition of safe space. People often describe the library as a sanctuary for those who are different, as well as a safe space for learning (Brewster, 2014; Maxwell, 2006). In reality, academic library environments created by library employees have the potential to be unsafe for innovation and learning (Madriaga, 2010; Mickiewicz, 2015).

\section{Definition of Safe Space}

The definition of safe space in the higher education environment is a space where faculty, staff, and students can feel secure and free to express themselves, learn, and achieve without censure or harm (Booker, 2007). Moderators of a safe space, whether physical, virtual or conceptual, construct this space with ground rules for discourse and behavior (Ada Initiative, 2015a; Ada Initiative, 2015b; Booker, 2007; Fembot Collective, 2014; Gay, Lesbian, and Straight Education Network, 2015; Jones, 2009; Marchon, 2015; Pho \& Masland, 2014; Robsinson, Sterner \& Johnson, 2006; Ruggs \& Hebl, 2012; Thorne, 2014). Academic and technology-related conferences have begun to establish and enforce such ground rules in order to prevent sexual harassment, verbal abuse, and other behaviors that negatively impact peoples' ability to learn and share as respected equals (Ada Initiative, 2015a; Ada Initiative, 2015b; Fembot Collective, 2014).

\section{Academic Library Definition of Safe Space}

Academic librarians subscribe to a professional code of ethics as defined by the American Library Association Code of Ethics (American Library Association, 2008) or the International Federation of Libraries and Archives Code of Ethics for Librarians and Other Information Workers (International Federation of Libraries and Archives, 2012). Both codes of ethics state that librarians should ground their work in the following values in order to protect people, 
things, and ideas in the following principles (Wexelbaum, 2016):

- Support and protection of the free flow and exchange of information and ideas

- Protection of patron privacy and confidentiality in their library usage

- Equitable access to all library resources and services for all patrons

- Resistance of all forms of censorship

- Representation of all people, their viewpoints, and their languages in collections

- Non-judgmental, courteous service to all patrons

- Non-judgmental, courteous interactions with all colleagues for the good of the library. Ideally, academic librarians, following their professional code of ethics, should construct safe spaces within the library. In reality, they often perceive innovations as disrupters and as potentially dangerous (Alliance Library System, n.d.; Graham, 2013). Academic libraries have traditionally defined safety through policies and procedures to protect employees, patrons, library resources, and the physical building itself from harm (Alliance Library System, n.d.; Graham, 2013; Halsted, Clifton \& Wilson, 2014; Mickiewicz, 2015; Wexelbaum, 2016). They have designed smart practices for handling emergencies (Halsted, Clifton \& Wilson, 2014), cybersecurity (American Libraries Association, 2015), as well as "inappropriate behavior" (Alliance Library System, n.d.; Graham, 2013).

Academic librarians, particularly LGBT librarians, subscribe to a grand narrative that libraries are safe spaces for all who are different (Gay, Lesbian, and Straight Education Network, 2015; Schrader, 2009; Vaillancourt, 2013), and that librarians should act as social justice warriors by teaching the rest of campus how to create spaces that stimulate learning and expression (Gittings, 1990; Mehra \& Braquet, 2007). Ironically, academic libraries rarely, if ever, label themselves safe spaces, undergo safe space training, or participate in campus climate assessments. They believe that maintaining neutrality in their work, through the provision of space for everyone and all types of activities, representation of all viewpoints in the collection, and non-judgmental assistance to patrons seeking information on any topic, automatically creates a safe space.

\section{Definition of Digital Scholarship}

Digital scholarship is defined as "the use of digital evidence and method, digital authoring, digital publishing, digital curation and preservation, and digital use and reuse of scholarship” (Rumsey, 2011). While researchers in the natural and social sciences have used digital methods to support their work for over fifty years, digital scholarship as an academic field of study officially took off with the emergence of the Internet and Web 2.0 technologies. Digital scholarship encompasses disciplines such as digital humanities and scholarly communication. Higher education institutions seeking to promote interdisciplinarity and defend the relevance of humanities and social sciences support the infusion of STEM (computer science in particular) into these disciplines, and seek to use new media and technologies to discover and communicate information in new ways to people from a wide variety of communities, disciplines, and professions.

\section{HOW LIBRARIES SUPPORT DIGITAL SCHOLARSHIP}

Since 2012, academic libraries around the world have begun to support digital scholarship through investment in interactive computer labs, makerspaces, multimedia studios, and emerging technologies. A significant number of four-year college and university libraries already have the digital infrastructure that allows collaborative learning and digital 
scholarship. On top of that, most software and applications required for digital scholarship are open source and cost almost nothing to use. For example, even if an institution cannot afford the \$10,140 annual site license for Oxygen XML Editor for text encoding projects, several free XML editing programs are available online for download.

As digital scholarship advances in academia, an increasing number of academic librarians are acquiring skills in computer programming, Web design, text encoding, geographic information systems and mapping, data analysis and storage, app development, online gaming, and 3D animation. As most librarians already have expertise in the digital scholarship areas that college faculty often lack, such as copyright management, digital rights management, metadata, and management of content management systems and institutional repositories (Dresselhaus, 2015; Keener, 2015; Marcum, 2014; Posner, 2013; Rumsey, 2011; Russell, 2013; Schaffner \& Erway, 2014; Sinclair, 2014), the new technical skills that they learn actually help them with their work in creating wayfinding maps and games to help patrons navigate the library, as well as digitizing print resources and making those new electronic resources compatible with data analysis programs such as R. It is now possible for librarians to show students and faculty how to search databases such as Hathi Trust to find evidence of certain word usage, language trends, popularity of public figures, or other information that will answer a research question.

Academic librarians who acquire the skills of digital scholarship are perceived by their faculty colleagues as equal players in research, and mentors in digital preservation, archiving, and storytelling, hence serving as a vehicle for academic libraries to build community (Sinclair, 2014; Thorne, 2014; Vandegrift, Varner, \& Verner, 2013). When academic libraries support digital scholarship on campus, they maintain their relevance to students and faculty. Students searching for assistance with digital projects and emerging technologies appreciate knowing that librarians can help them with these things without criticism, especially if they choose the library as their space to study and do homework. This breathes new life into the traditional librarian image of an unfashionable, pedantic bibliophile (Arant \& Benefiel, 2002; Pho \& Masland, 2014).

Most importantly, the practice of digital scholarship in the library has the potential to create a space where students, faculty and librarians can share their knowledge and learn from each other in a non-competitive environment. In particular, open makerspaces and digital scholarship activities in the library may encourage students without a background in STEM, particularly women, students of color, and those from underserved high schools, to explore coding and technologies, and determine whether or not they would want to take STEMrelated coursework (Ada Initiative, 2015a; Ada Initiative, 2015b; Robinson, Sterner \& Johnson, 2006; The Roestone Collective, n.d.; Thorne, 2014). Such a space would imply that the creators of that space are open-minded and secure enough in their expertise to empower a new generation of future scholars to show what they know. As higher education institutions pursue interdisciplinarity and active, collaborative learning, the academic library has an opportunity to show the campus how to achieve it through digital scholarship.

The new generation of graduate students trained in digital scholarship methods may expect to find the same research support and tools in the institutions where they land faculty positions. Graduate students often rub elbows with faculty and librarians at workshops, retreats, "unconferences", and intensive trainings where facilitators have learned the pedagogies necessary to create a safe environment for discussing elements of digital scholarship, learning how to use the tools, and creating content. Students, particularly females and students of color, are seeking social networks where they can learn coding, digital storytelling, Wikipedia editing, and other skills in supportive, collaborative environments 
(Ada Initiative, 2015a; Ada Initiative, 2015b; Robinson, Sterner \& Johnson, 2006; The Roestone Collective, n.d.; Thorne, 2014). As academic librarians take a more active role in participating in these shared learning environments and the production of digital scholarship, they are starting to assess whether or not their libraries are appropriate spaces—and if librarians are the appropriate people - to support digital scholarship pedagogies such as collaborative learning and experimentation (Coble, Potvin \& Shirazi, 2014; Russell, 2013; Schaffner \& Erway, 2014; Sinclair, 2014; Vandegrift, 2012; Vandegrift, Varner \& Varner, 2013).

\section{HOW TECHNOLOGY IMPACTS A SAFE SPACE FOR DIGITAL SCHOLARSHIP IN THE LIBRARY}

Academic librarians have grounded their reference and instruction, public services, and collection development in the values espoused by the American Library Association Code of Ethics and the International Federation of Libraries and Archives Code of Ethics for Librarians and Information Workers, which construct safe spaces for the free flow of information and ideas. It has been much harder to apply these same codes of ethics to technical services, systems, and emerging technologies.

Limitations of operating systems and platforms, programming languages, database construction, and even the standard vocabularies used by catalogers and archivists impact how people can access and share information, as well as how people can communicate with each other about what they experience while using library systems and new technologies. This impacts the working culture of those engaged with technology. Library employees engaged in maintenance and development of these systems work very hard to protect the content from viruses or hackers while trying to determine how to provide safe access for patrons. The language they use to describe every piece of their work is often so specialized that only those who are also engaged in this work would have access to the conversation.

Library employees steeped in technology do not always have the same pedagogical training as reference and instruction librarians might have to create a nonjudgmental, constructivist space for learning or discussion of complex subjects such as technology. For this reason, the working culture of those library employees whose main work revolves around technologies often shuts out other colleagues who do not have the formal training, but are interested in learning more about it or have new ideas about it. Complicating this issue are the gender and ideological divides that often exist between male and female library employees working with technologies, as well as traditional and futurist librarians (Gorman, 2004; Harris, 1999; Record \& Green, 2008). The work culture of librarians can inhibit safe spaces for digital scholarship in the library if librarians with a "directive" working and management style, as opposed to those with a "connective" working and management style, are in charge of library technology (Record \& Green, 2008).

Millennial librarians feel most comfortable learning and working in collegial and developmental cultures (Emanuel, 2012, p. 46-47; Russell, 2013). Librarians who wish to pursue digital scholarship tend to be younger, often female, with a futurist mindset and a “connective” working and management style (Graybill, 2014; Record \& Green, 2008). This new generation of academic librarians view themselves as researchers or emerging technologists trained to collaborate with, as opposed to serve, faculty in other disciplines (Keener, 2015; Russell, 2013). They do not react well to a "directive” working culture or management style (Wilder, 2007). The pedagogies that the new generation of librarians employ with students also differ from the older generation of librarians accustomed to 
delivering one-shot library instruction sessions (Russell, 2013). Some institutions hire the young new librarians for their extensive training in digital scholarship, even if they do not yet have a Masters in Library and Information Science (Vandegrift, 2012; Wilder, 2007). Their presence and activities threaten older generation librarians, particularly male-identified librarians, who practice "directive” working and management styles (Park, Scott \& Schnabel, 2014). This type of conflict can lead to microaggressions and bullying in the workplace, which negatively impacts the safety of library space for everyone.

Academic librarians who master technologies required for digital scholarship are not always the same librarians who master pedagogical theories used to teach information literacy. Today's reference and instruction librarians are infusing their work with "critical librarianship", a movement steeped in race theory, feminist theory, and queer theory that attempts to construct safe, non-judgmental library space for discussion, discovery, and active learning. Based on Friere's model of pedagogy for the oppressed, feminist pedagogy is an educational movement that changes the power dynamic from teacher versus student to "humans learning together" (Accardi, 2013). The goal of this pedagogy is for the teacher to serve as a facilitator of learning rather than the keeper of all knowledge, allowing students to bring their realities to the classroom and find meaning through that reality. This would include allowing students to employ their own vocabularies to describe their research process or work with technologies. Feminist pedagogy empowers both the teacher and student to take action on solving problems together, rather than focusing on learning the right answer. As librarians engage with diverse patrons to help them locate information, or teach them how to find and evaluate information, they are starting to embrace feminist pedagogy as a strategy to create non-judgmental safe space for learning and sharing of information. Successful makerspaces, hackerspaces, creativity labs, media studios, Wikipedia events, and engaging library instruction sessions all employ elements of feminist pedagogy to build a community of learners and a safe space for learning.

While some academic libraries spend a great deal of effort and money on designing new spaces for digital scholarship, they forget that physical and online academic library spaces often cause "library anxiety" for patrons (Bonnand \& Hansen, 2015; Madriaga, 2010; Mellon, 1986; Soria, Nackerud \& Peterson, 2015), thus discouraging them from exploration or use of the library altogether. Students often find academic libraries, their websites, and their online resources overwhelming. They also feel intimidated by librarians, whom they often perceive as judgmental and "knowing everything." Libraries that integrate emerging technologies, makerspaces, and digital scholarship opportunities in their spaces without providing empowering, supportive facilitation can jeopardize their success by making female patrons and other disenfranchised groups feel unwelcome or unsafe in those spaces (Ada Initiative, 2015a; Ada Initiative, 2015b; Booker, 2007; Fembot Collective, 2014; Gay, Lesbian, and Straight Education Network, 2015; Jones, 2009; Marchon, 2015; Pho \& Masland, 2014; Robsinson, Sterner \& Johnson, 2006; Ruggs \& Hebl, 2012; Thorne, 2014).

\section{CHALLENGES IN MAKING A SAFE SPACE FOR DIGITAL SCHOLARSHIP IN ACADEMIC LIBRARIES}

As of August 2015, most digital scholarship programs and centers in the United States exist at 
private institutions, Research I institutions ${ }^{2}$, and small liberal arts colleges. These institutions developed the first digital scholarship degree and certification programs for graduate students and professionals. Higher education institutions consider re-envisioning the library as the hub for digital scholarship a smart practice (Lippincott, Hemmasi \& Lewis, 2014; Marcum, 2014; Johnson, Adams Becker, Estrada, \& Freeman, 2015; Schaffner \& Erway, 2014; Sinclair, 2014; Vandegrift, Varner \& Varner, 2013). However, regional comprehensive institutions and community colleges have been slow to make any type of space for digital scholarship in the library, for practical and cultural reasons.

Institutional and administrative factors often erect barriers to interdisciplinary digital scholarship (Posner, 2013; Schaffner \& Erway, 2014). Digital scholarship is largely dependent on IT support. In higher education institutions, mission-critical IT services include email, financial systems, student enrollment, and course management systems; in the library, mission-critical IT support involves the catalog, Open URL resolvers, and other discovery layers (Posner, 2013, p. 49). Small, understaffed libraries may think twice about taking librarians and IT staff away from daily operations to pursue new initiatives or support "pet projects" of a few faculties.

According to Posner, libraries starting out with digital humanities work may have one librarian with the title "Digital Scholarship Librarian," "Digital Initiatives Librarian," or "Scholarly Communication Librarian" who also engages in other tasks such as reference, instruction, or collection development. This librarian may work with IT staff, or supervise IT staff, who also have other responsibilities. In other cases, the library may have one self-taught entrepreneurial librarian with a personal interest in digital scholarship who seeks out library resources and engagement with other faculty to do this work.

If the other librarians see digital scholarship as a competing agenda to their traditional work, and do not know how to integrate digital literacy into their library instruction, this will retard advancement of digital scholarship support in the library (Posner, 2013, p. 45). If library deans do not make investments in released time and other incentives for librarians to pursue the work, and if college deans do not recognize digital scholarship as a legitimate scholarship, then the digital scholarship program will develop piecemeal, without a coherent plan, clear direction or incentives required to keep it sustainable (Posner, 2013, p. 44). Even worse, if the library dean tasks people with implementing digital scholarship initiatives in the library without proper support, library employees will resent this work, and their attitudes will impact the quality of support they provide to patrons or colleagues interested in learning or working together.

Makerspaces, Wikipedia edit-a-thons, hackerspaces and other collaborative learning situations hosted in the library encourage students and faculty of all disciplines to learn valuable STEM skills from each other in a perceived non-judgmental, social environment. Academic librarians also perceive that library involvement in digital scholarship maintains their relevance on university campuses (Dresselhaus, 2015; Pho \& Masland, 2014; Vandegrift, 2012). At the same time, "traditional” librarian culture still views collaboration with other units within their physical library space as a threat (Vandegrift, Varner \& Varner, 2013). A relationship exists between institutional culture and change: "[w]here strategies for change violate cultural norms, change most likely will not occur” (Kezar \& Eckel, 2002, citing Eckel, Hill \& Green, 1998 and Schein, 1985). Academic librarians, even those working

2 Research I institutions in the United States offer a full range of baccalaureate programs, are committed to graduate education through the doctoral level, and give high priority to research. 
together within one unit, have a diversity of perspectives on library culture, academic culture, and their role in one or both environments (Kezar \& Eckel, 2002). Clashes can arise among librarians who perceive the library as a conservative managerial culture and those who work within exploratory collegial and developmental cultures.

According to Mintzberg, Ahlstrand, and Lampel (2009), "successful change flows from learning, growth, and development” (p. 344). This implies that as librarians continue to learn new things, what they learn has the potential to change their thinking, and possibly change the work culture and strategic direction of their library. In order to make positive change to the work culture as a peer among peers, it is important that the workplace acts as a safe space for change discourse (McClellan, 2011). If librarians suppress each other's ideas for innovation, they will fail to create an authentic, non-judgmental learning space for patrons. If the librarians with "directive” working and management styles remain in control of technology and instruction, they will increase "library anxiety" among patrons and sour potential relationships with faculty engaged in digital scholarship work without realizing it (Record \& Green, 2008).

Embracing and promoting digital scholarship requires new skill sets and an ideological shift for librarians, from expert to participant in the learning process. If library employees in a unit cannot experience and share the joy of learning amongst themselves for fear of looking incompetent, they will not create a safe exploratory environment for faculty colleagues and students. Exploring digital scholarship as a service in the library means that librarians must reflect upon their own work culture, and revisit their concept of library as safe space for learning. Digital scholarship took off as an emerging discipline and academic trend in the second decade of the $21^{\text {st }}$ century. Many librarians are still trying to understand the discipline and how they fit into it (Coble, Potvin \& Shirazi, 2014; Dresselhaus, 2015; Schaffner \& Erway, 2014; Vandegrift, 2012). Academic librarians have written detailed plans on building digital scholarship programs, centers, and support services within their libraries. These plans focus mainly on the acquisition of skills, resources, and software, but have not called for an assessment of the individual library's culture to determine whether the unit is ideologically prepared to take on initiatives that may run contrary to the nature of their work.

\section{HOW ACADEMIC LIBRARIES CURRENTLY ASSESS SAFE SPACES FOR DIGITAL SCHOLARSHIP}

Now and then, the professional literature will address whether or not librarian culture and digital scholarship are compatible (Dresselhaus, 2015; Vandegrift, 2012; Vandegrift, Varner \& Varner, 2013). Library plans to develop digital scholarship services, programs or centers in the library focus on assessing librarian skill sets, library resources, physical learning spaces, and building relationships with faculty engaged in digital scholarship (Dresselhaus, 2015; Lippincott, Hemmasi \& Lewis, 2014; Schaffner \& Erway, 2014; Vandegrift, Varner, \& Varner, 2013). At this time, however, no literature exists to show how librarians perceived or assessed the climate of their learning environment, or if they actively created a safe space for learning as their unit pursued digital scholarship. This absence may give readers the impression that all academic librarians share the same open-minded, curious, collaborative, sharing culture that digital scholarship promotes, when in fact the opposite may be true.

Academic libraries often use LibQUAL + to assess patron satisfaction with library resources and services. The Web-based quantitative LibQUAL+ survey, developed by the Association of Research Libraries and Texas A\&M University, includes "22 core survey items [that] measure perceptions of service quality in three dimensions: Affect of Service, 
Information Control, and Library as Place” (LibQUAL+, 2016). Questions in the Affect of Service and Library as Place categories have the capability to provide some introductory data about library climate and perceived safety within library spaces for learning, working and leisure, but none of the LibQUAL + questions address satisfaction with technology instruction or provision of digital scholarship in the library, the spaces for such work, or whether there are barriers to participate in those activities. While many libraries do use LibQUAL+ results to improve their library resources and services, no research literature exists to show how libraries take data from this survey to change their institutional culture to improve library climate.

Academic libraries also employ the Measuring Information Service Outcomes (MISO) survey, "a Web-based quantitative survey designed to measure how faculty, students, and staff view library and computing services in higher education” (MISO, 2016). The MISO survey assesses the technological skill level of patrons, what skills they wish to learn, what library and technological services and resources are important to patrons, and how patrons perceive the effectiveness of communication and delivery of these resources and services (MISO, 2016). MISO does not include any questions that ask patrons to describe their overall learning experience in the library, their experience learning about technologies or digital scholarship in the library, or whether they perceive that the library is a safe space or not. While the MISO Survey Leadership Team attempts to engage those academic libraries who complete the survey to turn insights from their data into actions for improvement, no research literature exists to show how libraries have taken data from the MISO survey to change their institutional culture to improve library climate.

Women, LGBTIQ populations, faculty and students of color, people of different religious faiths, and the disabled are often sought out to provide a holistic assessment of barriers to success on their campuses in the form of holistic campus climate studies (Britton, Baird, Dyer, Middendorf, Smith, \& Montelone, 2012; Hart \& Fellabaum, 2008; Manning, Pring \& Glider, 2014; Mayes, 2014; Rankin \& Reason, 2008; Vaccaro, 2014; Vogel, Holt, Sligar \& Leake, 2008). At this time, neither library-specific nor STEM-specific safe space assessment tools exist (Hart \& Fellabaum, 2008; Rankin \& Reason, 2008). Campus climate assessment tools, however, may provide some guidance for the assessment of a safe space for digital scholarship in the library. While the term safe space never appears in these holistic campus climate assessments, campus climate studies often require that students, faculty, staff or administrators address barriers to equal opportunity or hostile environments that they have experienced while on campus (Hart \& Fellabaum, 2008; Rankin \& Reason, 2008). While some tools are more popular than others, the common practice for many campuses is to use a "homegrown" assessment instrument, often untested (Hart \& Fellabaum, 2008; Rankin \& Reason, 2008). These assessment tools focus on interactions with others, comments that they hear from others, trust, comfort levels in the classroom, dormitories, and administrative offices. The assessment tools do not ask participants about the library, and participants' comments about the library are not typically shared by the researchers in their articles. Research about the results of campus climate studies for faculty also do not take note of perceptions of campus climate or workplace climate for academic librarians in the same institution. More work needs to be done by academic librarians, perhaps in conjunction with student affairs professionals or other entities on campus, to assess the climate of the library and whether or not it provides a safe space for learning. 


\section{RECOMMENDATIONS AND QUESTIONS TO ASK}

Every higher education institution, and the academic library that supports it, has a unique culture that impacts its internal work with digital scholarship, as well as how it supports the digital scholarship work of students and faculty. Each academic library will have to first discover this for themselves, then determine the necessary actions it will need to take in order to create safe space for digital scholarship in the library. As most libraries have not even begun to assess their climate, this section of the article is divided into two parts: recommendations that will help all academic libraries begin to create safe space for digital scholarship, and following that, a series of questions that libraries should ask in order to assess whether or not their library actually provides a safe space for digital scholarship.

\section{Recommendations for Creating a Safe Space for Digital Scholarship}

This set of recommendations for creating safe space for digital scholarship in the academic library has been adapted from the book chapter "Libraries as Safe Spaces” (Wexelbaum, 2016):

- Review all mission and vision statements, policies, procedures, and strategic plans for the library to determine how they address safe space and technology. The library as a whole must provide safe spaces for employees and patrons, for all types of activities including digital scholarship. Does the library identify itself as a safe space in any of these documents, or strive to become one? Even if the documents do not use the exact term, how do these documents address how the library provides safe space, in alignment with IFLA and ALA Code of Ethics? Do they address patron privacy and provide privacy policies for all software and applications supported on campus? Does the library have its own antidiscrimination policy or equitable access policy? If they do not, does the strategic plan include any goals to revisit these documents with the intention of improving the climate, identifying safe spaces within the library, or improving such spaces? How do the mission and vision statements, policies, procedures, and strategic plans address creating safe spaces for digital scholarship in the library?

- Provide ongoing, reflective, critical cultural competency training for all library employees. Safe space training, along with all other cultural competency trainings, should not be one-off efforts. All library employees should set a personal and professional goal each year to address a bias or blind spot that they may have, and administration should schedule a weekly or monthly time for employees to come together, share their process in achieving their goals, discuss where they may be struggling, and provide support for one another in a non-judgmental space.

- Develop equitable, enforceable guidelines for behavior and technology use in the library that make the library a safe space. What type of rules for behavior and technology use does your library have? Do they emphasize courtesy and non-judgmental, collegial behavior that stimulates community building and collaborative learning, or do the rules simply tell patrons what they can or cannot do? Guidelines for netiquette, Creative Commons licensing, and clear paths to seeking permissions can be posted in spaces in the library used for digital scholarship, as well as made available online. Review your library's rules for behavior and technology, and rewrite them through a differently abled, anti-racist, anti-classist, feminist, LGBT-friendly lens.

- Provide signage that tells patrons how they can use different spaces. If faculty or students have no experience with co-working spaces or open maker spaces or studios, they might not feel comfortable entering those spaces on their own without some welcome or 
instruction. Also, it is important for patrons to know what floors and spaces in the library are completely quiet spaces for individual study, and which floors and spaces are for talking and group work. This will also inform patrons what computer labs they can use for collaborative work.

- Consult with campus disability services when designing new spaces and acquiring technologies for digital scholarship. According to the ALA and IFLA Codes of Ethics, library resources and services must be accessible for all users. To ensure that differently abled faculty and students can make use of all spaces and technologies in the library, furniture and online resources must be adjustable for their needs, and library employees should receive training on how to adjust the size of text on screens, activate speech to text recognition in word processing programs, and provide captioning for all instructional media. This consideration for patrons with special needs will come at little or no cost to the library, and will benefit a wider swath of the campus population than is visible.

- Evaluate digital scholarship promotional materials for diversity. Do library promotional materials and the library website reflect the diversity on campus? Do technology-related promotional materials show girls, women, people of color, the differently abled, and nonbinary individuals engaging in digital scholarship at the library?

- During outreach efforts, find out why people don't use the library for digital scholarship. How do non-library users in the community perceive the library space? What do they perceive is not present, or unsafe?

\section{Questions to Ask to Assess Library as a Safe Space for Digital Scholarship}

In order to transform library culture, library faculty and staff must "challenge existing assumptions and beliefs in order to align with the environment” (Kezar, 2014). Library faculty and staff often use data from research studies, surveys and focus group interviews as reflection tools to help drive changes. The following series of questions will employ such strategies in order to identify and prioritize what aspects of a library's culture need to be changed in order to create a safe space for digital scholarship. Depending on their individual situation, a library may choose to focus on one or more of these questions, in no particular order, in order to develop an action plan that takes their staffing, resources, and relationship with their campus into account.

- What is the general climate of the library as perceived by its employees? Do library employees perceive their work environment and culture as open, collaborative, and supportive? What is the attitude of library employees toward experimentation and risktaking? Where do inequities exist among library employees, and what barriers exist for library employees in accomplishing their work, learning new skills, or trying to make use of new skills? If library employees do not trust one another, if certain library employees with "all of the knowledge" do not mentor others, and if divisions exist between library employees who work with technology and those who do not, these problems will affect any new or existing services that the library will provide to campus. An outside consultant or facilitator may need to collect this data from library employees in a way to preserve security and confidentiality, then generate solutions for improvement.

- What is the general climate of the library as perceived by patrons? If the upper administration wishes to conduct a campus-wide climate survey, the library dean should involve themselves in the process to find out how questions about the library can be integrated in the climate survey. Data collected from the climate survey will inform the library if and how they are providing a safe space for learning, work, and leisure on 
campus, and if any populations are facing barriers or microaggressions. These results should be shared with all library employees in order to devise agreed upon action items for improvement.

- How does the library understand and prioritize digital scholarship? Do library employees have a common understanding of digital scholarship? Which library employees engage in digital scholarship support or create digital scholarship products themselves? Do they work with faculty, staff, and students from other units on campus to inform this work, or do they believe that they are the "experts" who should teach the campus "how it should be done"? Answers to these questions will help library administration understand what type of training and support library employees may need if they want library employees to make digital scholarship a priority, as well as how to scale a digital scholarship initiative based on the number of library employees engaged or interested in this work, and their skill set.

- How does the campus understand and prioritize digital scholarship? Students and faculty will have different definitions of digital scholarship. These variations in understanding will depend on how each population currently engages with technology in their discipline, and how each distinct subculture within the institution employs digital scholarship at the time. If the library has a liaison program, liaisons to each unit on campus can begin to ask faculty in different departments, as well as students during library and technology instruction sessions, a set of common questions about how they describe, learn about and use digital scholarship. Faculty and student responses will give librarians a picture of the "digital scholarship culture" on campus, and how librarians might fit into it.

- How do library employees currently use the library space to engage in digital scholarship? What spaces do library employees currently use to work individually or in groups on projects? Do librarians and staff work together in the same space on common projects, or do they work in their individual offices and cubicles, and communicate via email and social media? What improvements to library space, if any, do library employees believe would help them learn about or engage in digital scholarship?

- How do faculty and students currently use the library space to engage in digital scholarship? What spaces in the library do faculty and staff currently use to work individually or in groups on projects? Do they use technology provided by the library, or do they bring their own? If they are not using the library for digital scholarship, why not? Is it because the library does not have appropriate hardware or software, because the current spaces do not allow for certain types of activities, or because there is insufficient (or unpleasant) human support or instruction in the library for their activities? Information gathered from this study may provide justification for a maker space, a media laboratory, or a creative studio, and what type and level of human support should exist in that space. Reference librarians, public service staff, or IT employees may be the best people to collect this information, as they are the ones monitoring spaces and assisting people with technology.

- How do faculty and students perceive the quality of library instruction, technology instruction, and technology support right now? If the library has participated in the LibQUAL+ or MISO survey recently, the library can take the data and comments to find out the strengths and weaknesses of these library services, and turn that data into action steps for improvement.

- What is the philosophy of teaching, and the teaching style, of those library employees engaged in library instruction, technology instruction, and technology support right now? 
Does the library still engage in traditional forms of instruction, or has anyone embraced feminist pedagogy? Are all forms of instruction in the library requested by faculty for their class support? Do library employees provide workshops open to all students, faculty, or both, where the library employee (or faculty or staff member from another unit on campus) simply serves as a facilitator for the learning? Depending on the answers to these questions, it may be a good idea to schedule some group discussions among those who teach information literacy, those who teach technology, and non-library faculty in the library in order to share successful teaching strategies, common challenges, and find out how to collaborate in order to foster safe spaces for digital scholarship in the library.

- Who is "the face" of library instruction and technology instruction in the library right now? Do a diverse team of people provide library instruction, technology instruction, and other workshops to students and faculty? Does a peer mentoring program exist in the library where student employees or volunteer students can teach their peers about technology and digital scholarship? Do library employees ever co-teach with faculty or staff from other units on campus? Are student employees or graduate students allowed to facilitate workshops in the library, or is any teaching in the library "owned" by librarians? To reduce library anxiety and engage campus constituents, people who provide any form of instruction in the library should be as open, friendly, and approachable as possible. They should find out what students or faculty want to learn, as well as how they want to learn it, and tailor their instruction or workshops to meet their needs.

At this time, no official safe space or climate survey exists for academic libraries, let alone an assessment of safe space for a particular activity. The recommendations and list of questions may serve as a catalyst to develop such an assessment instrument. It is the author's hope that increased awareness of the academic librarian's role in the provision of safe spaces for learning - also known as the free flow and exchange of information and ideas-will help people in our profession not only to redesign library spaces for digital scholarship, but also to empower everyone to learn and teach how to use new media and technologies to improve the human condition.

\section{REFERENCES}

Accardi, M.T. (2013). Feminist pedagogy for library instruction. Sacramento, CA: Library Juice Press.

Ada Initiative. (2015a). AdaCamp toolkit. Retrieved from https://adacamp.org/

Ada Initiative. (2015b). Anti-harassment work. Retrieved from https://adainitiative.org/what-we-do/conference-policies/

Alliance Library System. (n.d.). Safe harbor: Policies and procedures for a safe library. Retrieved from http://will.state.wy.us/ldo/boards/SafeWorkplace.pdf

American Library Association. (2008). The American Library Association code of ethics.

Chicago, IL: American Library Association. Retrieved from http://www.ala.org/advocacy/proethics/codeofethics/codeethics

American Library Association. (2015). The Cybersecurity Intelligence Sharing and Protection Act (CISPA). Retrieved from http://www.ala.org/advocacy/cispa

Arant, W., \& Benefiel, C.R. (Eds.). (2002). The image and role of the librarian. Binghamton, NY: Haworth Press.

Brewster, L. (2014). The public library as therapeutic landscape: A qualitative case study. Health \& Place, 26, 94-99. 
Bonnand, S., \& Hansen, M.A. (2015). Invisible community? Bringing online graduate students to the library. In S. Bonnand (Ed.) Innovative solutions in building community in academic libraries (pp. 1-15). Hershey, PA: IGI Global.

Booker, K.C. (2007). Perceptions of classroom belongingness among African American college students. College Student Journal, 41(1), 178.

Britton, D.M., Baird, C.L., Dyer, R.A., Middendorf, B.J., Smith, C., \& Montelone, B.A. (2012). Surveying the campus climate for faculty: A comparison of the assessments of STEM and non-STEM faculty. International Journal of Gender, Science and Technology, 4(1), 102-122.

Coble, Z., Potvin, S., \& Shirazi, R. (2014). Process as product: Scholarly communication experiments in the digital humanities. Journal of Librarianship and Scholarly Communication, 2(3), 1-10.

Dresselhaus, A. (2015). Opportunities beyond electronic resource management: An extension of the course competencies for electronic resources librarians to digital scholarship and scholarly communications. The Serials Librarian, 68, 361-369.

Eckel, P., Hill, B., \& Green, M. (1998). On change: En route to transformation (Occasional Paper, no. 1). Washington, DC: American Council on Education.

Emanuel, J. (2012). The millennials: Assessing the next generation of academic librarians (Doctoral dissertation, University of Missouri-Columbia).

Fembot Collective. (2014, Nov 7). The fembot toolkit. Retrieved from http://fembotcollective.org/blog/2014/11/07/the-fembot-toolkit/

Gay, Lesbian, and Straight Education Network. (2015). Libraries as safe spaces. Retrieved from http://www.glsen.org/article/libraries-safe-spaces

Gittings, B. (1990). Gays in library land: The Gay and Lesbian Task Force of the American Library Association: The first sixteen years. Philadelphia, PA: B. Gittings.

Gorman, M. (2004). Whither library education? New Library World, 105(9/10), 376-380.

Graham, W. (2013). Keeping your library safe: Blackbelt librarians [Presentation]. Retrieved from https://infopeople.org/civicrm/event/info?reset=1\&id=81

Graybill, J.O. (2014). Millennials among the professional workforce in academic libraries: Their perspective on leadership. The Journal of Academic Librarianship, 40(1), 10-15.

Halsted, D.D., Clifton, S.C., \& Wilson, D.T. (2014). Library as safe haven: Disaster planning, response, and recovery: A how-to-do-it manual for librarians. Chicago, IL: American Libraries Association. Retrieved from https://www.alastore.ala.org/detail.aspx?ID=4233

Harris, R.M. (1999). Gender and technology relations in librarianship. Journal of Education for Library and Information Science, 40(4), 232-246.

Hart, J., \& Fellabaum, J. (2008). Analyzing campus climate studies: Seeking to define and understand. Journal of Diversity in Higher Education, 1(4), 222-234.

International Federation of Libraries and Archives. (2012). IFLA Code of Ethics for Librarians and Other Information Workers (full version). Retrieved from http://www.ifla.org/news/ifla-code-of-ethics-for-librarians-and-other-informationworkers-full-version

Johnson, L., Adams Becker, S., Estrada, V., \& Freeman, A. (2015). NMC Horizon Report: 2015 Higher Education Edition. Austin, Texas: The New Media Consortium. Retrieved from https://net.educause.edu/ir/library/pdf/HR2015.pdf

Jones, S.K. (2009). The community library as site of education and empowerment for women: Insights from rural Uganda. Libri, 59(2), 124-133. 
Keener, A. (2015). The arrival fallacy: Collaborative research relationships in the digital humanities. DHQ: Digital Humanities Quarterly, 9(2). Retrieved from http://www.digitalhumanities.org/dhq/vol/9/2/000213/000213.html

Kezar, A. (2014). How colleges change: Understanding, leading, and enacting change. New York: Routledge.

Kezar, A., \& Eckel, P.D. (2002). The effect of institutional culture on change strategies in higher education. The Journal of Higher Education, 73(4), 435-459.

LibQUAL+. (2016). Survey FAQs. Retrieved from http://www.libqual.org/about/about_survey/faq_survey

Lippincott, J.K., Hemmasi, H., \& Lewis, V.M. (2014, Jun 16). Trends in digital scholarship centers. Retrieved from http://www.educause.edu/ero/article/trends-digital-scholarshipcenters

Madriaga, M. (2010). "I avoid pubs and the student union like the plague”: Students with Asperger Syndrome and their negotiation of university spaces. Children's Geographies, 8(1), 39-50.

Manning, P., Pring, L., \& Gilder, P. (2014). Wellness for all: Improving campus climate for LGBTQA students as prevention. Journal of College \& Character, 15(2), 119-124.

Marchon, C. (2015, Mar 3). Investigating online feminist forums: Where are the safest spaces? Fembot. Retrieved from http://fembotmag.com/2015/03/03/investigatingonline-feminist-forums-where-are-the-safest-spaces/

Marcum, D. (2014). The digital transformation of information, education, and scholarship. International Journal of Humanities and Arts Computing, 8, 1-11.

Maxwell, N.K. (2006). Sacred stacks: The higher purpose of libraries and librarianship. Chicago, IL: American Library Association.

Mayes, T. (2014). Campus climate and the underrepresented minority engineering student experience: A critical race study. (Doctoral dissertation, University of California, San Diego and California State University San Marcos). Retrieved from WorldCat Dissertations. (893578204).

McClellan, J.G. (2011). Reconsidering communication and the discursive politics of organizational change. Journal of Change Management, 11(4), 465-480.

Mehra, B., \& Braquet, D. (2007). LIS professionals as community action researchers in an academic setting: Top ten directions to further institutional change for people of diverse sexual orientations and gender identities. Library Trends, 56(2), 542-565.

Mellon, C.A. (1986). Library anxiety: A grounded theory and its development. College \& Research Libraries, 47(2),160-165.

Mickiewicz, P. (2016). Access and its limits: The contemporary library as a public space. Space and Culture, 19(3), 237-250.

MISO. (2016). The MISO survey: Measuring higher education library and IT services. Retrieved from http://www.misosurvey.org

Mintzberg, H., Ahlstrand, B., \& Lampel, J. (2009). Strategy safari: Your complete guide through the wilds of strategic management ( $2{ }^{\text {nd }}$ ed.). Harlow, England: Financial Time Prentice Hall.

Park, B., Scott, R., \& Schnabel, J. (2014). Generations in Tennessee libraries. Tennessee Libraries, 64 (3). Retrieved from http://www.tnla.org/?page=TL64_3_generations

Pho, A., \& Masland, T. (2014). The revolution will not be stereotyped: Changing perceptions through diversity. In N. Pagowsky \& M. Rigby (Eds.) The librarian stereotype: Deconstructing perceptions and presentations of information work. Chicago, IL: Association of College \& Research Libraries. 
Posner, M. (2013). No half measures: Overcoming common challenges to doing digital humanities in the library. Journal of Library Administration, 53(1), 43-52.

Rankin, S., \& Reason, R. (2008). Transformational tapestry model: A comprehensive approach to transforming campus climate. Journal of Diversity in Higher Education, 1(4), p. 262-274.

Record, A., \& Green, R. (2008). Examining gender issues and trends in library management from the male perspective. Library Administration \& Management, 22(4), 193-198.

Robinson, C., Sterner, G., \& Johnson, T. (2006). Don't build it and they will come: Creating space for wholeness, meaning, and purpose in higher education. Journal of College \& Character, 7(6), 1-4.

Ruggs, E., \& Hebl, M. (2012). Diversity, inclusion, and cultural awareness in the classroom and outreach education. In B. Bogue \& E. Cady (Eds.), Apply research to practice $(A R P)$ resources. Retrieved from https://www.engr.psu.edu/AWE/ARPAbstracts/DiversityInclusion/ARP_DiversityInclu sionCulturalAwareness_Overview.pdf

Rumsey, A.S. (2011). New-model scholarly communication: Roadmap for change (Scholarly Communication Institute 9). Charlottesville, VA: Scholarly Communication Institute, and University of Virginia Library. Retrieved from http://www.uvasci.org/institutes2003-2011/SCI-9-Road-Map-for-Change.pdf

Russell, J. (2013, Jan 24). Teaching digital scholarship in the library [Web log post]. Retrieved from $d h+l i b$ blog, http://acrl.ala.org/dh/2013/01/24/teaching-digitalscholarship-in-the-library/

Schaffner, J., \& Erway, R. (2014). Does every library need a digital humanities center? Dublin, Ohio: OCLC Online Computer Library Center, Inc. Retrieved from http://www.oclc.org/content/dam/research/publications/library/2014/oclcresearchdigital-humanities-center-2014.pdf

Schein (1985). Organizational culture and leadership: A dynamic view. San Francisco: Jossey-Bass.

Schrader, A.M. (2009, Apr 17). Challenging silence, challenging censorship, building resilience: LGBTQ services and collections in public, school, and post-secondary libraries. Conference paper presented at the British Columbia Library Conference, Burnaby, British Columbia, Canada.

Sinclair, B. (2014, Jun 30). The university library as an incubator for digital scholarship. EDUCAUSE Review. Retrieved from http://www.educause.edu/ero/article/universitylibrary-incubator-digital-scholarship

Soria, K.M., Nackerud, S., \& Peterson, K. (2015). Socioeconomic indicators associated with first-year college students' use of academic libraries. The Journal of Academic Librarianship, 41 (5). doi:10.1016/j.acalib.2015.06.011

The Roestone Collective. (n.d.). Safe space: Towards a reconceptualization. Antipode, 46(5), 1346-1365.

Thorne, E. (2014). Digital storytelling: A safe space for creative expression (Master's research project). Eugene, Oregon: University of Oregon Libraries. Retrieved from https://scholarsbank.uoregon.edu/xmlui/handle/1794/18474

Vaccaro, A. (2014). Campus climate for diversity: Current realities and suggestions for the future. Texas Education Review, 2(1), 129-137.

Vaillancourt, S. (Jan 2013). Libraries as safe spaces. American Libraries, 44(1/2), 30. 
Vandegrift, M. (2012, June 27). What is digital humanities and what's it doing in the library? In the Library with a Lead Pipe. Retrieved from http://www.inthelibrarywiththeleadpipe.org/2012/dhandthelib/

Vandegrift, M., Varner, M., \& Varner, S. (2013). Evolving in common: Creating mutually supportive relationships between libraries and digital humanities. Journal of Library Administration, 53(1), 67-78.

Vogel, S., Holt, J.K., Sligar, S., \& Leake, E. (2008). Assessment of campus climate to enhance student success. Journal of Postsecondary and Disability, 21(1), 16-31.

Wexelbaum, R. (in press). Libraries as safe spaces. In S. Hines (Ed.) Advances in library administration and organization: The future of library space, 35. Emerald.

Wilder, S. (2007). The new library professional. Chronicle of Higher Education, 53(25), C1C4. 